\title{
Non-pharmacological approaches to control pediatric cancer pain: nursing team view*
}

\author{
Métodos não farmacológicos no controle da dor oncológica pediátrica: visão da equipe de \\ enfermagem
}

Mayara Ruiz Chotolli ${ }^{1}$ Paula Batista Luize²

${ }^{*}$ Received from Cancer Hospital of Barretos, Barretos, SP, Brazil.

DOI 10.5935/1806-0013.20150021

\section{ABSTRACT}

BACKGROUND AND OBJECTIVES: A new challenge for pediatric cancer is pain control and it is believed that different professionals should be involved in this process, including the nursing team. So, there is the need for nursing care evaluation with regard to pain in cancer children. This study aimed at identifying pain measurement scales and non-pharmacological methods used by a pediatric nursing team.

METHODS: This is a descriptive, exploratory study carried out with 35 nursing professionals of the Children and Adolescents Cancer Hospital of Barretos, from June to September 2014. A questionnaire with 36 questions was used, added of 4 more for nursing professionals, related to the objective of the study. Data were analyzed by the SPSS v21.0 program.

RESULTS: There has been a small number of right answers with regard to the adequate use of scales for children from zero to 2 years of age. Only 3 (21.4\%) nurses have chosen the Neonatal Infant Pain Scale. Most common non-pharmacological methods were: comfort measures $(n=22)$, massage $(n=18)$, environmental changes $(n=16)$ and heat $(n=16)$. Nevertheless, it was observed that among 15 subjects suggesting other methods, 10 have mentioned drugs. Only $4(28.6 \%)$ nurses prepared nursing pain-related diagnoses and 7 (50\%) believed that their care helped in pain management.

CONCLUSION: We have identified the need for training on pain measurement scales according to age, possible non-pharmacological methods used by the nursing team and their association with the nursing process.

Keywords: Child, Nursing team, Nursing team professional, Oncology, Pain management, Pediatrics.

1. Children and Adolescents Cancer Hospital of Barretos, Pediatric Intensive Therapy Unity, Barretos, SP, Brazil.

2. Cancer Hospital of Barretos, Surgical Center, Barretos, SP, Brazil.

Submitted in January 06, 2015.

Accepted for publication in May 15, 2015.

Conflict of interests: none - Sponsoring sources: none.

Correspondence to:

Mayara Ruiz Chotolli

Rua Antenor Duarte Vilela, 1331 - Doutor Paulo Prata

14784-400 Barretos, SP, Brasil.

E-mail: mayarachotolli@hotmail.com

(C) Sociedade Brasileira para o Estudo da Dor

\section{RESUMO}

JUSTIFICATIVA E OBJETIVOS: Um dos novos desafios para o câncer infantil é o controle da dor, e acredita-se que diversos profissionais devem estar envolvidos nesse manuseio, inclusive a enfermagem. Dessa forma, nota-se a necessidade de avaliaçóes do cuidado de enfermagem em relação à dor de crianças em tratamento oncológico. O objetivo deste estudo foi identificar escalas de mensuração da dor e métodos não farmacológicos utilizados por uma equipe de enfermagem da pediatria.

MÉTODOS: Trata-se de um estudo descritivo exploratório, realizado com 35 profissionais de enfermagem no Hospital de Câncer Infanto-Juvenil de Barretos, de junho a setembro de 2014. Foi utilizado um questionário com 36 questóes, acrescidas de 4 para o profissional enfermeiro, relacionadas ao objetivo da pesquisa. Os dados foram analisados com a ajuda do programa SPSS v21.0.

RESULTADOS: Obteve-se um número reduzido de acertos em relação ao uso correto de escalas para crianças de 0 a 2 anos; somente $3(21,4 \%)$ enfermeiros escolheram a escala Neonatal Infant Pain Scale. Os métodos não farmacológicos mais escolhidos foram: medidas de conforto $(n=22)$, massagem $(n=18)$, alteraçóes no ambiente $(n=16)$ e calor $(n=16)$. Apesar disso, notouse que entre os 15 sujeitos que sugeriram outros métodos, 10 citaram o fármaco. Verificou-se que somente 4 (28,6\%) enfermeiros elaboravam diagnósticos de enfermagem relacionados à dor, mas que 7 (50\%) acreditavam que seus cuidados auxiliavam no manuseio da dor.

CONCLUSÁO: Identificou-se a necessidade de treinamentos sobre escalas de mensuração de dor conforme a idade, possíveis métodos não farmacológicos utilizados pela enfermagem e sua associação com o processo de enfermagem.

Descritores: Criança, Equipe de enfermagem, Manuseio da dor, Papel do profissional de enfermagem, Pediatria, Oncologia.

\section{INTRODUCTION}

The number of hospitalized cancer children is increasing every day and with this, new challenges involving the disease and its management are constantly arising ${ }^{1}$. Among them, one may mention cancer children pain management ${ }^{1}$. Percentages are alarming because pain in cancer children is approximately $78 \%$ at diagnosis, 25 to $58 \%$ during treatment, and up to 
$90 \%$ in later stages of the disease ${ }^{2}$.

Pain is currently described as the fifth vital sign, so it is believed that nursing team is linked to potential interventions for children's pain relief ${ }^{3}$. Pain management involves from its evaluation to measures to promote patients' comfort and wellbeing and such actions lead to health promotion during treatment and hospital admission ${ }^{3}$. This way, it is critical for nurses to be knowledgeable about pain, its management and possible approaches for pain relief, to remain updated and assure quality and safety assistance ${ }^{1}$.

This study aimed at identifying non-pharmacological approaches for pain control used by the nursing team for hospitalized children and, at the same time, at evaluating most popular pain scales to characterize pain and at evaluating nursing team views as contribution to other health professionals to manage pain as from non-pharmacological approaches.

\section{METHODS}

This is a descriptive, exploratory, quali-quantitative study, carried out in a Children and Adolescents Cancer Hospital from Barretos-SP, which has an Admission Unit with 18 beds and an Intensive Care Unit (ICU) with 6 beds. The study was carried out with 35 nurses acting on above-mentioned units, in the period from June to September 2014.

A questionnaire with 36 questions (open and closed) related to pain measurement and evaluation by the nursing team, in addition to questions identifying non-pharmacological approaches was used for data collection. To these 36 questions, 11 items were included regarding variables: gender, age, time working with cancer children, function at the hospital, working sector and specialization. When professionals answered the questionnaire, 4 questions were added, dealing with nursing diagnosis and prescription.

Inclusion criteria were professionals working for three months or longer in the hospital, being them nurses, nursing technicians or assistants involved in nursing assistance to cancer children, in the admission unit and the pediatric ICU. Those on medical leave for 15 days or longer and those refusing to participate in the research were excluded.

Data were described in terms of mean, standard deviation, minimum, maximum and quartiles for quantitative variables and by frequency tables for qualitative variables, being analyzed by the program Statistical Package for the Social Sciences (SPSS) version 21.0.

In compliance with recommendations regarding research with human beings, approved by Resolution CNS 196/96, before data collection the project was submitted to appreciation by the Research Ethics Committee-CEP, in addition to having the consent of the institution and of participants. The project was approved by opinion 695390.

\section{RESULTS}

From 57 nursing professionals, 35 (67\%) participated in the research, $9(17 \%)$ were excluded for not meeting inclusion criteria, $3(5,7 \%)$ refused to participate and $5(9.6 \%)$ could not be interviewed during the data collection period.

Participated in the research 35 professionals, being $94.3 \% \mathrm{fe}-$ males. From these, 21 (60\%) were nursing technicians and 14 (40\%) were nurses. From nurses, 5 (35.7\%) had some type of specialization and just one female nurse was specialized in pediatrics, and one in oncology. Working places were: admission unit with $\mathrm{n}=22(62.9 \%)$ and ICU $\mathrm{n}=13(37.1 \%)$. And working shifts were: morning with $\mathrm{n}=13(37.1 \%)$, afternoon $\mathrm{n}=10(28.6 \%)$ and evening $\mathrm{n}=12(34.3 \%)$. Mean working time was 12 months (4-36).

After the question: "How often have you cared of children with pain in the last week?", 16 (47.1\%) have answered "always" and 14 (41.2\%) have answered "almost always".

It was observed that $29(82.9 \%)$ respondents have answered that they "always" evaluate pain of a child during vital signs investigation. Figure 1 shows the choice of pain scale according to age group.

With regard to non-pharmacological approaches, there were nine possible approaches and a Likert Scale was developed for people to check the frequency with which they use each approach. Results are shown in figure 2.

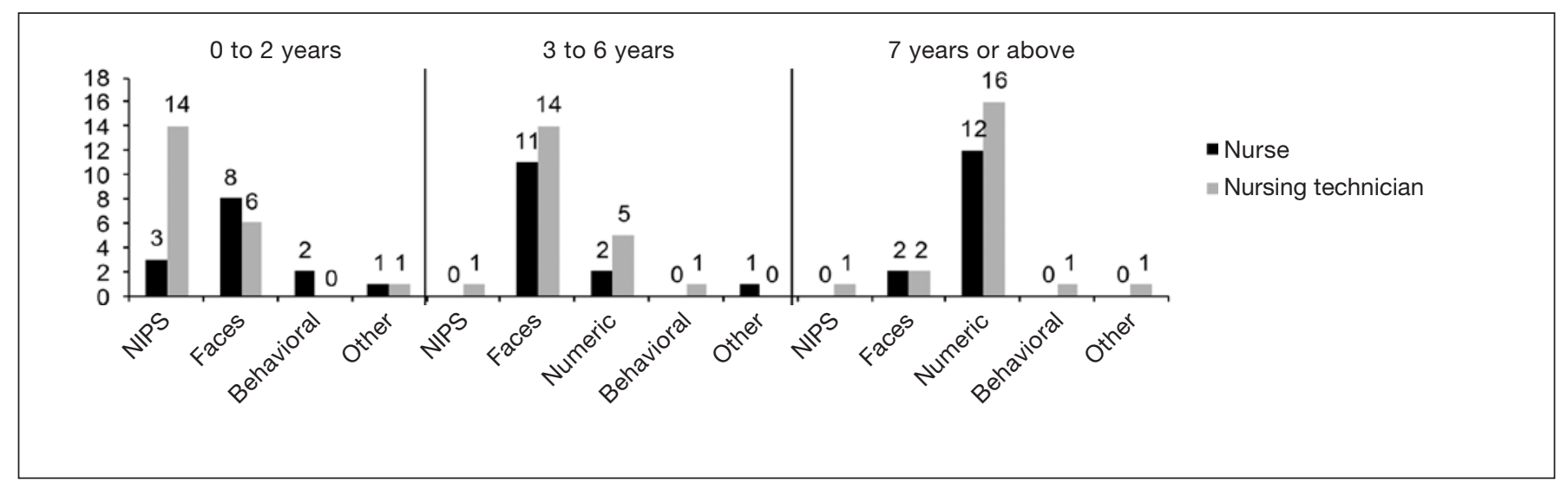

Figure 1. Pain measurement scales used by nurses and nursing technicians according to children's age group. Children and Adolescents Cancer Hospital of Barretos, 2014

NIPS = Neonatal Infant Pain Scale; Faces = faces scale; Behavioral = behavioral scale; Numeric = numeric scale. 


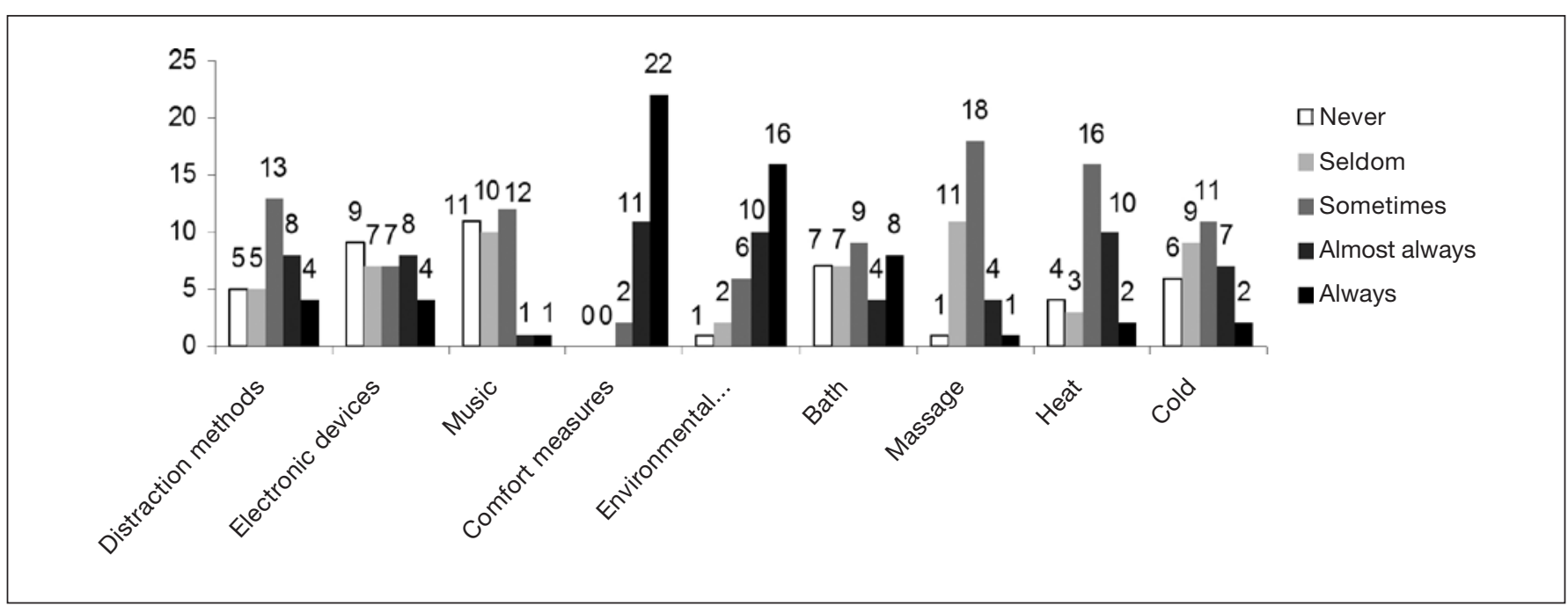

Figure 2. Frequency of approaches, according to a Likert Scale, checked by nurses and nursing technicians of the Children and Adolescents Cancer Hospital of Barretos, 2014

When asked: "Think about a child with pain; at the moment you see this child, can you think of a pain relief strategy different from analgesics?”, 27 (77.1\%) have answered yes. From these, 15 have suggested other approaches. The frequency of each approach was: $10(38.4 \%)$ for drugs, $9(34.2 \%)$ for distraction, 2 (7.6\%) for lap, 2 (7.6\%) for affection, 1 (3.8\%) for decreasing noise and $1(3.8 \%)$ for therapeutic touch.

From respondents, 29 (82.9\%) have mentioned more than one professional, different from physicians and nurses, who may contribute for children's pain relief. Among professionals, physiotherapist was mentioned $21(33.8 \%)$ times, followed by psychologist with $12(19.3 \%)$ and occupation therapist with 7 (11.2\%).

With regard to nursing diagnosis and assistance prescribed by nurses, $4(28.6 \%)$ have stated that "always" prepare pain-related nursing diagnoses and $5(35.7 \%)$ have stated "almost always". A total of $7(50 \%)$ nurses believed that their prescribed assistance would help improving pain. Major approaches were: patients' comfort $\mathrm{n}=9(29.0 \%)$ and drugs $\mathrm{n}=5(16.2 \%)$. Other approaches were: pain evaluation $\mathrm{n}=2(6.4 \%)$, affection $\mathrm{n}=2(6.4 \%)$, heat $\mathrm{n}=2(6.4 \%)$, attention $\mathrm{n}=2(6.4 \%)$, massage $\mathrm{n}=2(6.4 \%)$, psychological support $\mathrm{n}=1(3.2 \%)$, chatting $\mathrm{n}=1$ $(3.2 \%)$, lap $\mathrm{n}=1(3.2 \%)$, singing $\mathrm{n}=1(3.2 \%)$, clap hands $\mathrm{n}=1$ $(3.2 \%)$, placebo $\mathrm{n}=1(3.2 \%)$ and environmental changes $\mathrm{n}=1$ $(3.2 \%)$.

\section{DISCUSSION}

Pain evaluation is the first stage for correct decision-making and adequate therapy ${ }^{1}$. In pediatrics, pain should be measured according to age groups and this is the first and probably the most important step to start any intervention ${ }^{2}$.

Pain is a subjective and individual experience so there is no single tool able to measure pain with extreme fidelity; however there are scales which allow nurses to measure pain, provided the professional complements this evaluation with semiologic pain analysis ${ }^{3}$.

Children have different ways to express pain, so it is necessary to understand childhood developmental and behavioral stages $^{4}$. A study has observed that a research has identified difficulty to evaluate pain among infants and preschoolers who expressed themselves exclusively by crying 5 .

Our research has shown difficulty of the nursing team in choosing pain measurement scale, especially for children aged 0 to 2 years. This shows the need for training so that professionals are skilled to use adequate scales for each child.

A Finnish study has shown that $75 \%$ of nurses believe that pain scales are important to be used with neonates, however $60 \%$ considered possible to evaluate neonatal pain without scales ${ }^{6}$.

A second study has shown that nurses use more often neonatal pain evaluation scales than physicians, who base their evaluation on behavior, body reactions, vital signs changes, stress and decreased oxygen saturation ${ }^{7}$.

Scales should be simple and facilitate the use by all professionals. It is recommended that nurses evaluate which scale should be used for pain measurement in children and record such data, updating them daily ${ }^{8}$.

In the studied institution the use of pain scales according to children age group and conditions is standardized. Notwithstanding this being a standard, not all respondents answers were adequate and this might be related to the time working with the institution, which was relatively short, approximately 12 months, and to the low number of pediatrics and oncology specialization. A limitation of this study might have been the establishment of working time of "three months or longer".

It was noted that the more qualified is the pediatrics or neonatology professional, there is significant increase in knowledge, especially about pain matters'. A UK study has shown that some professionals $(1.5 \%)$ disagreed that a premature with less than 28 weeks would feel pain ${ }^{7}$. In a different study, 
$100 \%$ of respondents believed that neonates feel pain, being that 80 to $100 \%$ believed that they feel equal or more severe pain than adults?

Training on the subject should be ongoing for children pain evaluation and control to be effective, thus assuring quality assistance ${ }^{10}$. Nurses have a major role in pain management, that is, monitoring and implementation of alternative measures for its handling ${ }^{11}$. Inadequate treatment is largely associated to the isolated work of a single professional, rather than a group ${ }^{11,12}$.

One respondent has evidenced the importance of nursing in controlling pain:

"Because nurses are responsible for most care and follow up during treatment, I have established an affective link of confidence and resolution, especially at the moment of pain or during uncomfortable procedures" [respondent 17].

It was observed that respondents have confirmed the help of numerous professionals for handling pain, showing that they know how to identify professionals who should be involved with pain therapy.

With regard to non-pharmacological pain relief approaches, there has been prevalence of the following: comfort measures, environmental changes, massage and heat. And it was noticed that when subjects answered that they used a different approach $^{10}$, they would mention a drug rather than a non-pharmacological approach.

Drugs were mentioned several times, including in one statement:

"Sometimes, nursing care may even improve children's pain, but most of the times you need to medicate" [respondent 30].

One subject has considered that time available for using other methods different from drugs is short, as evidenced by the statement:

"(...) the profession requires a lot from us and we are not always able to give the attention they deserve" [respondent 1].

However, a different subject has mentioned that link is essential to establish nursing care:

"When it is possible to establish a link, it is possible to identify strategies for pain relief according to each patient and sometimes in an early manner" [respondent 2].

It is necessary to advance with adjuvant therapies for pain relief, since a single therapeutic resource has not shown to be enough to control pain, especially chronic pain ${ }^{13}$.

For children and adolescents, studies have shown the importance of associating drug therapy to arts, reading, music and recreational activities, in addition to health professional welcoming and listening ${ }^{14}$. For neonates, according to the Ministry of Health $(\mathrm{MH})$, the following non-pharmacological measures are recommended: oral administration of sweet substances, non-nutritional suction, breastfeeding, skin-to-skin contact and decreased tactile stimulation ${ }^{15}$.
The World Health Organization (WHO) has established standards for the use of adjuvant therapies, that is, those added to drug therapy ${ }^{16}$. The document "Oncologic Palliative Care: Pain Control" ( $\mathrm{MH}$ - Brazil. National Cancer Institute, 2001), has a series of complementary and alternative measures, stressing physical, mechanical and cognitive methods ${ }^{16}$. Mentioned physical methods are: transcutaneous electric nerve stimulation, heat and cold manipulation ${ }^{16}$. Mechanical methods include massage and physical activity ${ }^{16}$. And cognitive methods mention relaxation and directed distraction, oriented imagination and deep breathing, biofeedback, educational groups, modeling, positive reinforcement and behavioral essay ${ }^{16}$.

However, notwithstanding all these techniques, it is necessary that professionals applying such techniques understand them and be competent according to their exercise law, not to generate risks ${ }^{13}$.

For example, heat manipulation is a technique inducing increased blood flow, decreasing pain perception and generating muscle relaxation, and joint stiffness, superficial inflammation and muscles spasm relief ${ }^{16}$. Professionals must know how to use this technique and understand that it becomes inadequate in cases of infection, active bleeding, vascular failure, tactile sensitivity changes and on sites with the presence of tumor ${ }^{16}$. The professional in charge must be duly trained and understand that this method may have consequences such as edema, vascular failure, ischemia, burnings and necrosis ${ }^{16}$.

This attention is related to nursing diagnosis and prescription. Nurses, as from such tools, may use their knowledge to prescribe complementary therapies of their competence, based on scientific arguments to protect patients and themselves. In our study, only $4(28.6 \%)$ nurses have stated that "always" perform pain-related nursing diagnosis.

A study with 118 premature infants assisted in a teaching hospital has shown percentages of nursing diagnoses performed by nurses of the unit, being that pain diagnosis was the $4^{\text {th }}$ most frequent, with $65.3 \%{ }^{17}$.

Nursing Assistance Systematization (NAS) allows care to gain theoretical and scientific reference, and at the same time assures that individuals' needs are met $^{18}$. NAS language makes possible for nurses to speak the same language in different sites by different profesionals ${ }^{18}$.

According to NANDA, nursing diagnoses defining pain are: acute and chronic pain. Acute pain is related to noxious agents (biological, physical, chemical and psychological), and for chronic pain factors are chronic physical and psychosocial incapacity ${ }^{19}$.

The book NIC- Nursing Interventions Classification (2008) has the following interventions for nursing diagnosis of chronic pain: acupressure (application of firm and continuous pressure on body sites to decrease pressure), analgesic administration, drug administration, simple massage, application of heat or cold, pain control, drugs control, biofeedback (helping patient to change a body function), environmental control or comfort, distraction, simple relaxation therapy ${ }^{20}$. For acute 
pain the following interventions are mentioned: acupressure, analgesic administration, drug administration, application of heat or cold, pain control, drugs control, environmental control or comfort, decreased anxiety, biofeedback, distraction, therapeutic game, simple massage, music therapy, guidance for image focusing, therapy with animals ${ }^{20}$.

Notwithstanding interventions and classifications, it seems that pain management is still difficult among professionals. The importance of professionals' involvement with its management is noted, however there is need for standardization of opinions, which could convey security for parents and children being assisted. In our study, no professional has recognized the importance of guidance about pain as nursing care.

A study has mentioned this dilemma and has shown the importance of incorporating subjects related to pain management to university nursing courses ${ }^{21}$. Lack of knowledge is becoming increasingly sensitive to the situation and brings further pain handling difficulties ${ }^{21}$. Empathy with parents and simple information about pain may be offered ${ }^{22}$. The literature shows that conveying information seems to be important for parents, who evaluate what is being reported by professionals and criticize when information differs from one professional to the other ${ }^{23}$.

\section{CONCLUSION}

Our study has observed that major difficulty of participants was pain measurement in children aged from 0 to 2 years and that drugs seem to be their first choice for pain relief.

The knowledge about non-pharmacological pain-relief approaches and scales for measuring pain in children should be incorporated since Nursing Graduation because nurses are knowledge spreaders and major players during pain evaluation and integration of the multidisciplinary team to control pain. In spite of numerous available non-pharmacological approaches and autonomy of nursing professionals to develop nursing prescriptions involving such approaches, compliance with NAS and pain involvement in the nursing process was low in our study, showing the need for further training and guidance for nursing professionals.

\section{REFERENCES}

1. Melo LR, Pettengill MA. Dor na infância: atualizaçấo quanto à avaliaçáo e tratamento. Rev Soc Bras Enferm Ped. 2010;10(2):97-102.

2. Alves Neto O. Dor: princípios e prática. Porto Alegre: Artmed; 2009.

3. Bottega FH, Fontana RT. A dor como quinto sinal vital: utilização da escala de avaliação por enfermeiros de um hospital geral. Texto Contexto Enf. 2010;19(2):283-90.

4. Dias FM, Afonso M, Sá TS, Marcelino AL, Santos MJ, Morita AB. A criança vítima de queimadura e sua dor no momento da realizaçáo de procedimentos diários: uma revisấo bibliográfica. Janus. 2008;5(8):33-43.

5. Bueno PC, Neves ET, Rigon AG. O manejo da dor em crianças com câncer: contribuiçōes para a enfermagem. Cogitare Enferm. 2011;16(2):226-31.

6. Pölkki T, Korhonen A, Laukkala H, Saarela T, Vehviläinen-Julkunen K, Pietilä AM Nurses' attitudes and perceptions of pain assessment in neonatal intensive care. Scand J Caring Sci. 2010;24(1):49-55.

7. Akuma AO, Jordan S. Pain management in neonates: a survey of nurses and doctors. J Adv Nurs. 2012;68(6):1288-301.

8. Lafleur KJ. Taking the fifth (vital sign). RN [periódico na Internet] 2004 Jul [acesso em 2015 Fev 20]; 67(7): [aproximadamente 3p.]. Disponível em: URL: http://www. modernmedicine.com/modern-medicine/content/taking-fifth-vital-sign.

9. Silva AP, Balda RC, Guinsburg R. Reconhecimento da dor no recém-nascido por alunos de medicina, residentes de pediatria e neonatologia. Rev Dor. 2012;13(1):35-44.

10. Silva MS, Pinto MA, Gomes LM, Barbosa TL. Dor na criança internada: a percepçáo da equipe de enfermagem. Rev Dor. 2011;12(4):314-20.

11. Pimenta CA. Dor: ocorrência e evolução no pós-operatório da cirurgia cardíaca e abdominal Rev Paul Enferm. 1992;11(1):3-10.

12. Menossi MJ, Lima RA, Corrêa AK. Pain and the challenge of interdisciplinarity in child care. Rev Lat Am Enfermagem. 2008;16(3):489-94.

13. Silva MD, Leăo E. Práticas complementares no alívio da dor. Dor: $5^{\circ}$ sinal vital: reflexôes e intervençôes de enfermagem Curitiba: Ed Maio; 2004. 121-33p.

14. Menossi MJ, Lima RA. A dor na criança e no adolescente com câncer: dimensôes de seu cuidar. Rev Bras Enferm. 2004;57(2):178-82.

15. Ministério da Saúde. Atenção à saúde do recém-nascido: guia para os profissionais de saúde. Brasília-DF Ministério da Saúde. 2011 [acesso em 13 de maio 2015]. Disponível em: http://bvsms.saude.gov.br/bvs/publicacoes/atencao_recem_nascido_\%20 guia_profissionais_saude_v2.pdf

16. Ministério da Saúde - Brasil. Instituto Nacional de Câncer. Cuidados paliativos oncológicos: controle da dor. Recuperado em 25 de Agosto de 2010, de http://wwwincagovbr/estimativa/2010/indexasp?link=conteudo_viewasp\&ID=2 2001:70-4.

17. Del'Angelo N, Góes FS, Dalri MC, Leite AM, Carvalho Furtado MC, Scochi CG Diagnósticos de enfermagem de prematuros sob cuidados intermediários. Rev Bras Enferm. 2010;63(5):755-61.

18. Laurent M, Dias V. A sistematização da assistência de enfermagem em pediatria. Programa de Atualização em Enfermagem: saúde da criança e do adolescente: PROENFciclo. 2006;1.

19. Association NAND. Diagnósticos de enfermagem da NANDA: definiçốes e classificação 2007-2008. Porto Alegre: Artmed; 2008. 548-9p.

20. Dochterman JM, Bulechek GM, Garcez RM. Classificaçáo das intervençôes de enfermagem (NIC). Porto Alegre, Artmed; 2008. 291-2p.

21. Nascimento LC, Strabelli BS, de Almeida FC, Rossato LM, Leite AM, de Lima RA. Mothers' view on late postoperative pain management by the nursing team in children after cardiac surgery. Rev Lat Am Enfermagem. 2010;18(4):709-15.

22. Zisk RY, Grey M, Medoff-Cooper B, Kain ZN. Accuracy of parental-global-impression of children's acute pain. Pain Manag Nurs. 2007;8(2):72-6.

23. Kankkunen P, Vehviläinen-Julkunen K, Pietilä AM, Halonen P. Is the sufficiency of discharge instructions related to children's postoperative pain at home after day surgery? Scand J Caring Sci. 2003;17(4):365-72. 